\title{
Research observation: Daily movement patterns of hill climbing and bottom dwelling cows
}

\author{
DEREK W. BAILEY, MARTINA R. KEIL, AND LARRY R. RITTENHOUSE
}

Authors are Associate Professor, Northern Agricultural Research Center, Montana State University, Havre, Mont., former graduate Research Assistant and Professor, Rangeland Ecosystem Science, Colorado State University, Fort Collins, Colo.

\section{Abstract}

Individual animal selection has been proposed as a tool for increasing uniformity of grazing on rugged rangeland. Daily grazing patterns of cows previously identified as preferring steeper slopes and higher elevations (hill climbers) were compared to cows preferring gentler slopes and lower elevations (bottom dwellers). Cows were ranked for slope use and vertical distance traveled to water during late summer in 1997 using horseback observers. In 1998, 9 extreme cows based on 1997 rankings ( 4 hill climbers and 5 bottom dwellers) were tracked using Global Positioning System (GPS) collars for 3 weeks during late summer on foothill rangeland. Hill climbers (1027 hours) arrived at water about 1 hour later $(P=0.04)$ than bottom dwellers (0928 hours). Hill climbers and bottom dwellers left water at the same time (1801 hours, $P=0.3$ ). During this interval, $90 \%$ and $98 \%$ of the observations were within 100 and 200 $\mathrm{m}$ of water, respectively. While cattle were away from water (1901 to 0846 hours), $56 \%, 77 \%$, and $87 \%$ of the observations were within 200, 300, and $400 \mathrm{~m}$, respectively, from the cow's location at 0700 hours. Hill climbers spent $14 \%$ of their time on steeper slopes ( 20 to 30 degrees) while bottom dwellers spent $7 \%$ $(P=0.01)$, and hill climbers $(41 \%)$ tended $(P=0.07)$ to spend less time on gentler slopes ( 0 to 10 degrees) than bottom dwellers $(47 \%)$. Hill climbers $(1323 \mathrm{~m})$ were observed at higher elevations $(P=0.01)$ than bottom dwellers $(1277 \mathrm{~m})$. Horizontal distance traveled to water $(633 \mathrm{~m})$ was similar $(P>0.1)$ for hill climbers and bottom dwellers. Cow location during the early morning (0700 hours) was a good predictor of terrain used during the morning and previous evening grazing bouts. Cows tracked in this study did not appear to regularly associate with each other. They usually grazed in different areas of the pasture and regularly used different water sources. Individual cows within a herd can use different terrain even though many aspects of the grazing patterns are similar. Location of cows during the early morning and perhaps the time that cows travel to water can be used to identify differences in terrain use among individual animals.

Key Words: Global positioning system, cattle, distribution, grazing behavior

This manuscript has been assigned Journal Series No. 2002-22, Montana Agricultural Experiment Station, Montana State University-Bozeman. This research was partially supported by the USDA Western Regional SARE program and by the NRI Competitive Grants Program/USDA, Award 9703712.

The authors would like to acknowledge and thank Robin Weinmeister, Randy Poser and Sarah Bucklin-Comiskey for their technical assistance with this manuscript.

Manuscript accepted 14 Mar. 03.

\section{Resumen}

La selección animal individual ha sido propuesta como una herramienta para incrementar la uniformidad del apacentamiento en los pastizales de topografía rugosa. Los patrones diarios de apacentamiento de vacas previamente identificadas de que prefieren pendientes pronunciadas y altas elevaciones (escaladoras de montaña) fueron comparadas contra vacas que prefieren pendientes suaves y bajas elevaciones (habitantes del fondo). Las vacas fueron clasificadas por el uso de la pendiente y la distancia vertical viajada para tomar agua durante fines del verano en 1997, para lo que se usó observadores montados a caballo. En 1998, 9 vacas ubicadas en los extremos de acuerdo a la clasificación de 1997 (4 escaladoras y 5 habitantes del fondo) fueron rastreadas durante 3 semanas a fines del verano en un pastizal de pie de montaña mediante collares con Sistema Global de Posicionamiento (GPS). Las escaladoras (1027 horas) arribaron al agua aproximadamente 1 hora mas tarde $(P=0.04)$ que las habitantes del fondo (0928 horas), las escaladoras y los habitantes del fondo dejaron el agua al mismo tiempo (1801 hours, $\mathbf{P}$ $=0.3$ ). Durante este intervalo, 90 y $98 \%$ de las observaciones estuvieron entre 100 y $200 \mathrm{~m}$ del agua respectivamente. Mientras el ganado estuvo alejado del agua (1901 a 0846 hours), $56 \%, 77 \%$ y $87 \%$ de las observaciones estuvieron dentro de los 200,300 y $\mathbf{4 0 0} \mathrm{m}$ respectivamente de la ubicación de las vacas a las 0700 horas. Las escaladoras gastaron $14 \%$ de su tiempo en las pendientes pronunciadas ( 20 a 30 grados) mientras que las habitantes del fondo gastaron solo el $7 \%(P=0.01)$ y las escaladoras $(41 \%)$ tendieron $(P=0.07)$ a gastar menos tiempo en pendientes suaves (0 a 10 grados) que las habitantes del fondo $(47 \%)$. Las escaladoras $(1323 \mathrm{~m})$ fueron observadas a mayores elevaciones $(P=0.01)$ que los habitantes del fondo $(1277 \mathrm{~m})$. La distancia horizontal viajada al agua $(633 \mathrm{~m})$ fue similar $(P>0.1)$ para las escaladoras y las habitantes del fondo. La ubicación de las vacas temprano por la mañana ( 0700 horas) fue un buen predictor del terreno usado durante la mañana y durante los periodos de apacentamiento de la tarde previa. Las vacas rastreadas en este estudio parecen no asociarse regularmente unas con otras, ellas usualmente apacentaron diferentes áreas del potrero y regularmente usaron diferentes fuentes de agua. Vacas individuales dentro de un hato pueden usar diferente terreno, aunque muchos aspectos de los patrones de apacentamiento son similares. La localización de las vacas temprano por la mañana y quizás el tiempo que las vacas viajaron al agua pueden ser usados para identificar diferencias en el uso del terreno entre animales individuales. 
Livestock grazing distribution is a critical concern for managing extensive rangelands. Selecting breeds and individual cows within a breed has been suggested as a management tool for improving the uniformity of grazing (Roath and Krueger 1982, Howery et al. 1996, 1998). Bailey et al. (2001b) found that Tarentaise cows, developed in the French Alps, used steeper slopes and traveled further vertically from water than Hereford cows, developed in England. These authors also found that cows sired by Piedmontese bulls developed in the foothills of the Italian Alps traveled further vertically from water than cows sired by Angus bulls developed in Scotland (Bailey et al. 2001a).

If cows that preferred gentle slopes near water (bottom dwellers) were culled and cows that preferred steeper slopes and areas further vertically or horizontally from water (hill climbers) were selected, uniformity of grazing of the herd could potentially be improved. Bailey (1999) identified 4 required conditions for individual animal selection for grazing distribution to be practical and effective: 1) There must be considerable variation in terrain use among individual animals to provide sufficient selection differential. 2) Terrain use must be easily measured or predicted for individual animals. 3) Terrain use must be heritable. 4) Performance of cows and their calves should not be adversely related to desired grazing patterns. Differences in terrain use observed among cattle breeds (Bailey et al. 2001a, 2001b) suggests that there is variation among animals, and those differences could be partially heritable. However, these observations were based on scan samples of all cows during the early morning by horseback observers. The potential variation of individual grazing patterns of cattle has not been evaluated on a 24-hour basis for longer periods ( $>7$ consecutive days). Location of cattle during the early morning has been suggested as a good indicator of the plant community where they did most of their grazing during a 24hour period (Low et al. 1981). This suggestion was based on observing cows for 24 hours every 2 weeks. Cattle move to new areas to forage each day (Bailey et al. 1990), and the efficacy of using early morning cow location to predict spatial grazing preferences should be examined by tracking cows for several consecutive days. If an animal's early morning location is an accurate indicator of where a cow grazes, such observations could be used to identify individual differences in grazing patterns within a herd.
Ungulates can be accurately tracked for long periods using global positioning system (GPS) equipment (Moen et al. 1997). With such equipment one can observe daily grazing patterns of cows on a 24hour basis for over 2 weeks and evaluate behavior at a temporal scale that was previously impractical to study. Our first objective of this case study was to compare and contrast daily grazing patterns of cows that used the steepest and highest terrain (hill climbers) to those that used the gentlest slopes and lower elevations (bottom dwellers) during the previous year's scan sampling. These extremes were chosen to exemplify the variability in terrain use that could occur within a herd. The second objective was to determine how well cow location during the early morning indexed spatial grazing preferences.

\section{Study Area}

The study was conducted in the Bear's Paw Mountains $25 \mathrm{~km}$ south of Havre, Montana (48 $\left.20^{\prime} 42^{\prime \prime} \mathrm{N} 109^{\circ} 35^{\prime} 59^{\prime \prime} \mathrm{W}\right)$. Cattle grazed in the Back pasture ( 337 ha) of the Thackeray Ranch (part of Northern Agricultural Research Center) from 23 July 1998 to 9 September 1998. Relief varies from 1184 to $1402 \mathrm{~m}$ with slopes ranging from 0 to 56 degrees. The pasture contained 3 perennial streams located near the east and west boundaries (Fig. 1). Lower elevations with gentle slopes were dominated by Kentucky bluegrass (Poa

\section{Methods}

pratensis L.), and steep slopes (> 20 degrees) were dominated by rough fescue (Festuca scabrella Torr.). Kentucky bluegrass, rough fescue, bluebunch wheatgrass (Pseudoregnaria spicata [Pursh] A Love), and Idaho fescue (Festuca idahoensis Elmer) were dominant in the majority of areas in each pasture. Standing crop of grasses in this pasture averaged $1500 \mathrm{~kg}$ $\mathrm{ha}^{-1}$ in 1998. Grasses compose 80 to $85 \%$ of the total herbaceous standing crop during most years. About $14 \%$ of the pasture supports an overstory of Ponderosa pine (Pinus ponderosa Laws) and aspen (Populus tremuloides Michx.).

Precipitation and weather during the study were typical for this site during late summer. Annual precipitation at the study site during 1998 was $42 \mathrm{~cm}$. The 15 -year (1984 to 1998) average annual precipitation at the study site was $41 \mathrm{~cm}$. The average daily temperature ranged from 17 to $27^{\circ} \mathrm{C}$, and the overall temperature during the study was $22^{\circ} \mathrm{C}$. The minimum daily temperature ranged from 9 to $19^{\circ} \mathrm{C}$ during the study, and the average minimum temperature was $13^{\circ} \mathrm{C}$. The maximum daily temperature during the study ranged from 27 to $36^{\circ} \mathrm{C}$, and the average maximum temperature was $32^{\circ} \mathrm{C}$.

\section{Cattle}

A total of 160 cows between the ages of 4 to 9 years grazed in the study pasture. Most of the cows had calves $(n=151)$, and a few were not lactating $(n=9)$. Cattle breeds included Hereford, Tarentaise, and Hereford x Tarentaise crosses. During

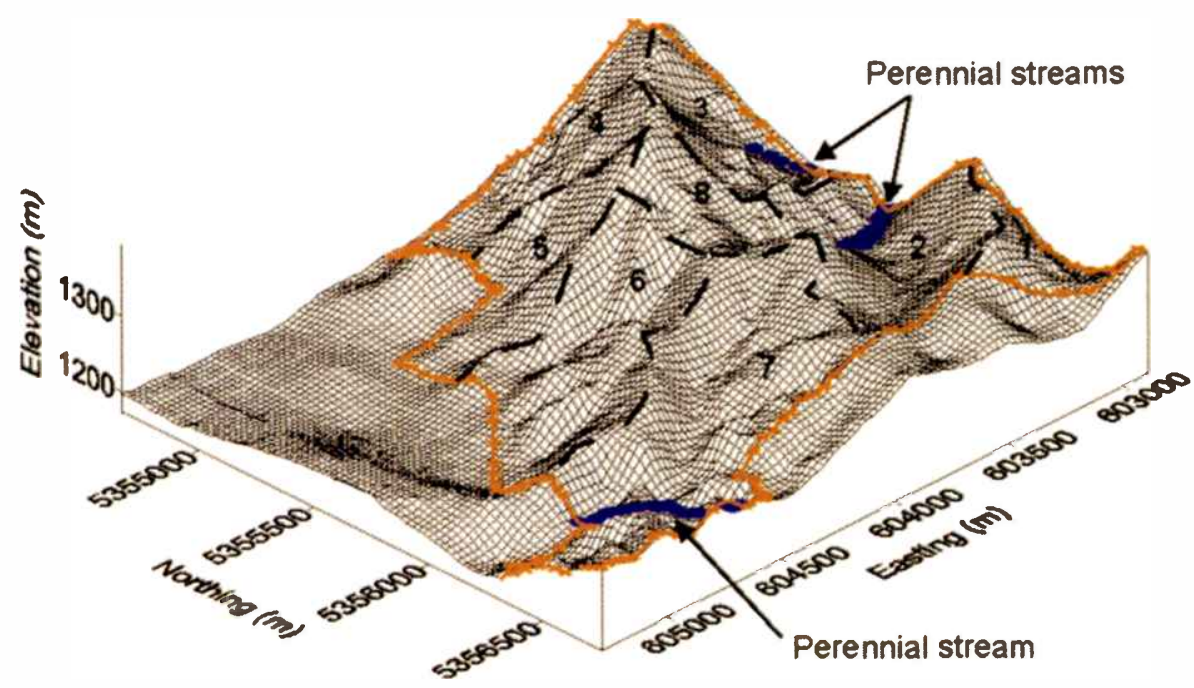

Fig. 1. Topography and locations of boundary fence, and water sources (perennial streams) within the study pasture (Back pasture). Dashed lines indicate boundaries of visual zones where topography prevents line of sight observation from other zones except for some areas greater than $\mathbf{5 0 0} \mathrm{m}$ away. Pasture was 337 ha in size, and topographic relief varied from 1184 to $1402 \mathrm{~m}$. 
August and early September in 1997 (year prior to this study), cows within the herd were ranked based on average slope use and vertical distance traveled to water in the Back pasture using cow locations recorded by horseback observers and procedures described by Bailey et al. (200lb). Higher-ranking cows (termed hill climbers) were observed on steeper slopes and at higher elevations (greater vertical distance to water) than lower ranking cows (termed bottom dwellers) that were observed on gentler slopes and at lower elevations. Four focal cows were randomly selected from the 16 highest-ranking cows (upper $10 \%$, hill climbers), and 5 focal cows were randomly selected from the 16 lowest ranking cows (lower 10\%, bottom dwellers). All focal cows had calves and had grazed in the study pasture annually since birth. During the 1998 grazing season, these 9 cows were continuously tracked for 8 to 22 days (Table 1).

\section{GPS Tracking}

Lotek GPS 2000 collars (Lotek Wireless, Newmarket, Ontario) were used to track the 9 focal cows. These collars contain global positioning system (GPS) receivers and are capable of recording animal position with a positional accuracy within 5 to $12 \mathrm{~m}$ after differential correction (Moen et al. 1997). A GPS receiver maintained at the Northern Agricultural Research Center, near Havre, Mont. and located $22 \mathrm{~km}$ from the study pasture was used for differential correction. The GPS coordinates received from the collars were converted from a latitude-longitude format to a Universal Transverse Mercator (UTM) format using CORPSCON geographic software (US Army Corps of Engineers, Washington, D.C.). Collars were placed on the focal animals on 3 dates (Tablel), because they were received from the manufacturer at different times. In all cases, tracking began at least 24 hours after placement of the collars on the cows to allow the animals to become accustomed to the apparatus. Positions of 8 of the focal cows were recorded every $10 \mathrm{~min}$ during the day (0500 to 2100 hours) and every $20 \mathrm{~min}$ at night (2100 to 0500 hours). The positions of 1 cow were recorded every $5 \mathrm{~min}$ because the collar was placed on the animal later (Table 1), and the battery life was sufficient to obtain positions at a more frequent interval.

\section{Cow Activity}

The tracking collars have vertical and horizontal motion sensors that can be used to monitor animal activity (Turner et al. 2000). Vertical head movements sensed by the collars are similar to the head movements sensed by vibracorders. In this study, we used the vertical motion sensor to classify animal activity during the interval between position fixes into 2 categories, active, and inactive. The motion sensor counted the number of vertical movements that occurred during 4-min periods. During the period between fixes $(5,10$, or 20 minutes), the average number of vertical movements was estimated. If the average number of vertical movements between position fixes was less than 25 / min, the animal was classified as inactive. Average number of movements greater than $25 /$ minute were classified as active. During May and early June 1999, collared cows $(n=12)$ were visually observed and fitted with vibracorders for 1 -week periods. Cows were observed for at least 4 hours per day and vibracorders recorded head movements continuously. Classifications of active and inactive behavior based on the collar readings were in agreement with visual observations $92 \%$ of the time and in agreement with vibracorder data $90 \%$ of the time. With these 2 classifications we could associate general behaviors with cow locations.

\section{Terrain Use}

To determine if grazing patterns of the groups varied during the study period, the horizontal distance to water, slope and elevation of the location of focal cows at 0700 hours was calculated from a digital elevation model of the pasture (US Geological Service) and the geographical coordinates from the GPS collars. Fence boundaries and watering locations were recorded using an 8-channel, L-band GPS receiver with $\pm 1 \mathrm{~m}$ positional accuracy (Omnistar, Houston, Tex.). Vertical distance to water at 0700 hours each day was calculated using the procedures described by Bailey et al. $(200 \mathrm{lb})$ from the geographical coordinates obtained from the GPS collars. Locations of cows during the early morning period may be a good predictor of where cows grazed during the current and previous grazing bouts (Low et al. 1981, Bailey et al. 1990).

Table 1. Dates and sampling intervals of focal cows that were tracked with global positioning system (GPS) collars.

\begin{tabular}{|c|c|c|c|c|c|c|}
\hline Cow & Breed & Age & Treatment & Tracking dates & Sampling interval & $n^{\prime}$ \\
\hline 0090 & $\underset{\text { Tarentaise }}{1 / 2}$ Hereford - $1 / 2$ & 8 & Hill climber & 27 Aug. to 9 Sept. & $\begin{array}{l}\text { Day - } 10 \text { min. } \\
\text { Night }-20 \mathrm{~min} .\end{array}$ & 2318 \\
\hline 1080 & Hereford & 7 & Bottom dweller & 21 Aug. to 9 Sept. & $\begin{array}{l}\text { Day - } 10 \mathrm{~min} . . \\
\text { Night }-20 \mathrm{~min}\end{array}$ & 2398 \\
\hline 1179 & $\begin{array}{l}\text { 1/4 Hereford }-3 / 4 \\
\text { Tarentaise }\end{array}$ & 7 & Hill climber & 19 Aug. to 9 Sept. & $\begin{array}{l}\text { Day - } 10 \mathrm{~min} . \\
\text { Night - } 20 \mathrm{~min} .\end{array}$ & 2269 \\
\hline 2036 & $\begin{array}{l}\text { 1/4 Hereford }-3 / 4 \\
\text { Tarentaise }\end{array}$ & 6 & Hill climber & I Sept. to 9 Sept. & Every 5 min. & 2056 \\
\hline 3024 & $\begin{array}{l}\text { 3/4 Hereford - } 1 / 4 \\
\text { Tarentaise }\end{array}$ & 6 & Bottom dweller & 19 Aug. to 9 Sept. & $\begin{array}{l}\text { Day - } 10 \mathrm{~min} . \\
\text { Night - } 20 \mathrm{~min} .\end{array}$ & 2415 \\
\hline 3055 & Hereford & 5 & Bottom dweller & 19 Aug. to 9 Sept. & $\begin{array}{l}\text { Day - } 10 \mathrm{~min} \\
\text { Night }-20 \mathrm{~min}\end{array}$ & 2236 \\
\hline 3102 & $\begin{array}{l}\text { 1/4 Hereford }-3 / 4 \\
\text { Tarentaise }\end{array}$ & 5 & Hill climber & 19 Aug. to 9 Sept. & $\begin{array}{l}\text { Day - } 10 \mathrm{~min} \\
\text { Night }-20 \mathrm{~min} .\end{array}$ & 2498 \\
\hline 3226 & $\begin{array}{l}\text { 1/2 Hereford }-1 / 2 \\
\text { Tarentaise }\end{array}$ & 5 & Bottom dweller & 28 Aug. to 9 Sept. & $\begin{array}{l}\text { Day - } 10 \mathrm{~min} \\
\text { Night }-20 \mathrm{~min} .\end{array}$ & 2140 \\
\hline 3227 & $\begin{array}{l}\text { 3/4 Hereford }-1 / 4 \\
\text { Tarentaise }\end{array}$ & 5 & Bottom dweller & 19 Aug. to 9 Sept. & $\begin{array}{l}\text { Day }-10 \mathrm{~min} \\
\text { Night }-20 \mathrm{~min} .\end{array}$ & 2481 \\
\hline
\end{tabular}

${ }^{1}$ Number of locations used in the analyses for each focal cow. Collars did not obtain a fix on every scheduled time most likely due to poor satellite geometry or obstruction of signals. 
Average slope use of each cow was computed from all collar data from each cow. Using a digital elevation model, the pasture was divided into 4 zones based on slope ( 0 to 10,10 to 20,20 to 30 , and greater than 30 degrees). The percentage of observations within each zone was calculated for each focal cow. Similar calculations were made for the elevation and horizontal distance to water.

\section{Movement To and From Water}

Cattle generally have 2 large grazing bouts, early morning and evening (Ganskopp 2001). During the interval between these bouts, cows often remain near water throughout the late summer months (Low et al. 1981, Porath et al. 2002). During this study, cows usually traveled to water in mid morning and remained near $(<200 \mathrm{~m})$ water until evening when they left to graze. Geographic information software (ArcView Tracking Analyst, Environmental Systems Research Institute, Redlands, Calif.) was used to visualize cattle movements within the pasture using the locations recorded by the GPS collars. The time that cattle began to travel to water was clearly identified as a change in movement (usually rate and direction) that ended with the animal at water. Journeys to water typically lasted less than $20 \mathrm{~min}$. The time cows left water was easily identified by distance traveled from water. The time cows first traveled to water (TW) and the time cows last left water (LW) was separately determined for focal cows for each day of observation. The total time at water was calculated using TW and LW. During the interval between TW and LW, the percentage of all focal cow locations within 50,100, and $200 \mathrm{~m}$ of water was calculated. The proportion of time that focal cows were inactive (resting) during this period was also calculated using the criteria discussed above. The purpose of these calculations was to evaluate how far cattle traveled from water during the interval between the morning and evening grazing bouts.

The GPS tracking collars have a sensor that can record ambient temperature every time a geographic fix is obtained. The temperature associated with TW fix (TW-T) and the temperature associated LW fix (LW-T) was also evaluated for each focal cow.

\section{Predicting Cattle Grazing Areas from Their Location in the Morning}

The location of cows during the early morning has been used to estimate where cows grazed during the current and previous grazing bout (Low et al. 1981, Bailey et al. 1990, 2001b). The locations of cows during the interval between 1 hour after cows last left water $(\mathrm{LW}+1)$ to 1 hour before cows subsequently returned to water (TW-1) were examined to evaluate how well an early morning observation could represent the location of cows during the evening, nighttime and morning grazing bouts. The rationale for adding 1 hour to LW and subtracting 1 hour from TW was to assure exclusion of travel time. Cattle locations during this period ( $\mathrm{LW}+1$ to TW-1) were compared to the cow's location at 0700 hours. During the study period, 0700 hours was shortly after sunrise, and cattle usually had begun grazing by that time. Sunrise at the beginning of the study was 0631 hours and 0659 hours at the end of the study. The percentage of observations within 100, 200, 300 and 400 $\mathrm{m}$ of the 0700 hours position were calculated for each foraging period $(\mathrm{LW}+\mathrm{l}$ to TW-1) for each focal cow.

\section{Tortuousity of Grazing Paths}

Grazing paths of 8 of the 9 focal cows were evaluated using a fractal dimension index (Milne 1990) to determine if the tortuousity of grazing paths of the 2 treatment groups (hill climbers vs. bottom dwellers) differed. A randomly selected cow (3224) was excluded from the analyses to equalize sample size between treatments. Fractal dimension is a relationship between a measured grazing path length and the unit length of measures (the independent variable). It is expressed by the formula:

$$
\mathrm{L}(\delta)=\mathrm{k} \delta^{(1-\mathrm{D})}
$$

where $\mathrm{L}$ is the grazing path length, $\mathrm{k}$ is the intercept, $d$ is the ruler length and D is the fractal dimension of the grazing pathway. Fractal dimensions that measure 2 dimensional movement patterns (grazing pathway) fall between 1 and 2 . A fractal dimension of 1 indicates a straight line, while a fractal dimension of 2 would indicate a movement pattern that completely fills the area evaluated. In this study, the grazing path was defined as the straightline distance between locations recorded by the GPS collars. A program developed by Theobald (1999) was used to calculate the mean fractal dimension of each of the 9 collared cows. Only movement patterns recorded during the morning grazing bout (0600 to 1000 hours) were used in this analyses.

Etzenhouser et al. (1998) used the fractal dimensions of grazing paths to determine if environmental heterogeneity affects foraging movements and behaviors of white tailed deer (Odocoileus virginianus) and Spanish goats (Carpa hircus). Differences in grazing patterns were observed between species, with deer exhibiting straighter pathways $(F D=1.27$ ) and goats exhibiting more tortuous pathways $(\mathrm{FD}=1.53)$. Bailey et al. (1996) suggested that large herbivores might spend less time in nutrient poor feeding areas and patches by decreasing the tortuousity of their grazing path (lower fractal dimension) and increase their time in nutrient rich feeding areas and patches by increasing the tortuousity of their grazing path (higher fractal dimension).

\section{Association Between Cows}

The Back pasture was divided into 8 visual zones (Fig. 1) where ridges and other topography blocked line of sight vision. In some cases, there could be line of sight vision between some zones, but the distance would have been over $500 \mathrm{~m}$. The percentage of mornings (0700 hours) that focal cows were in the same visual zone was calculated on a pair-by-pair basis. Based on chance alone, 2 focal cows should have been in the same visual zone at 0700 hours about $17 \%$ of the time. The purpose of the visual zones and this analysis was to determine if the focal cows were part of the same subherd or group during grazing and could influence another focal cow's grazing patterns. We assumed that cows were not associating with each other during grazing if they were in different visual zones and could not see each other. In addition, cows in separate visual zones should have minimal influence on the other's grazing pathway. An exception would be if animals were very near a visual zone boundary such as a ridgeline. Most ridgelines were relatively rugged and steep, and cows were usually on one side or the other during the morning grazing bout.

Watering locations were in 3 separate areas of the pasture (Fig. 1). Cows near one water source could not see cows at the other sources because of topographical relief. Two watering locations were at least $320 \mathrm{~m}$ from each other and the third location was over $1580 \mathrm{~m}$ from the other locations. The percentage of days that 2 focal cows were at the same watering location was calculated on a pair-by-pair basis. We assumed that cows at 1 watering source were not associating with cows at another watering location. By chance alone, 2 focal cows could be at same watering location $33 \%$ of the time. 


\section{Statistical Analyses}

Four statistical models were used to evaluate various aspects of the tracking data. For the time cows first traveled to water (TW), time cattle left water (LW), time at water, temperature when cattle traveled to water (TW-T), temperature when cattle left water (LW-T), percent of locations between TW and LW when cows were inactive and the percent of observations within 100 and $200 \mathrm{~m}$ of water during the period between TW and LW, a mixed model of analysis of variance was used (SAS 1985). Treatment (hill climber or bottom dweller), water source ( 1 of 3 perennial streams), and Julian date were considered fixed effects. Cow within treatment was a random effect and used in the error term for comparing treatment means $(0.897 \times$ cow within treatment MS + $0.103 \times$ Error MS). This model uses a split-plot analysis to account for the repeated measures on focal cows. Mead et al. (1993) reported that the problems with this commonly used approach occur when there are similarities among times (e.g., consecutives days were more similar than the first or last days). In this study, Julian day (i.e., time) was not an important $(\mathrm{P}<$
$0.05)$ factor except for TW and TW-T, which were temperature related. These behaviors changed during warmer weather. Warmer days were not consecutive and were scattered throughout the study. Some cows were not tracked continuously throughout the study, and this model adjusts for differences among days.

For the percentage of observations within $100,200,300$, and $400 \mathrm{~m}$ of the 0700 hour location during the period 1 hour after leaving water to 1 hour before traveling to water ( $L W+1$ to $T W-1)$, a similar mixed model of analysis of variance model was used (SAS 1985). Treatment (hill climber or bottom dweller) and Julian date were considered fixed effects. As in the former model, cow within treatment was a random effect and used in the error term for comparing treatment means. This model was also used to evaluate the slope, elevation, vertical distance to water and horizontal distance to water for 0700-hour location of focal cows.

In the former 2 statistical models, all percentage data were analyzed using a square root transformation as recommended by Steel and Torrie (1980). Results from the analyses of transformed data were nearly identical to the results obtained from the untransformed data. For ease of interpretation, untransformed means and analyses are presented.

Two-sample t-tests were used to compare the mean fractal dimension of hill climbers and bottom dwellers. Two sample t-tests were also used to compare the percentage of observations in each of the 4 slope zones. Mean use (percent of observations within each zone) was calculated separately for each focal cow. Similar analyses were conducted for cattle observations in elevation zones and zones of varying distance from water.

The association between cows was evaluated using a Chi-square goodness of fit test (Lehner 1979). Expected values were calculated using the use of visual zones and watering zones expected by chance, 17 and $33 \%$ respectively.

\section{Results}

\section{Terrain Use}

Overall grazing patterns of 4 of the 9 focal cows are shown in Fig. 2. All cows traveled throughout the majority of the
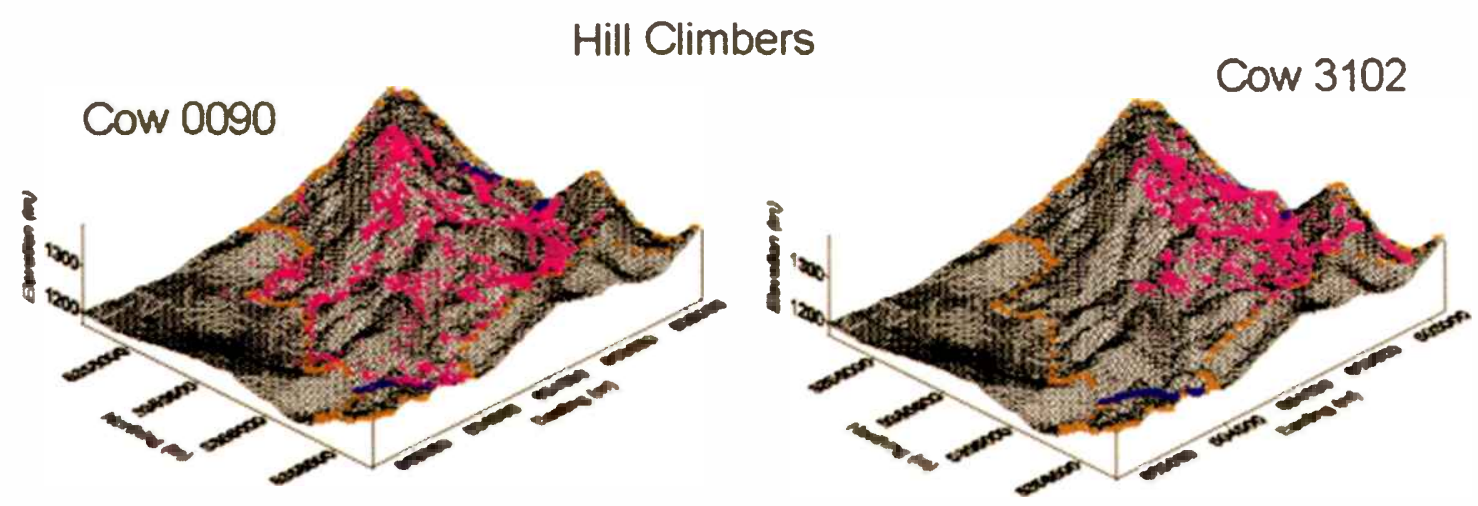

\section{Bottom Dwellers}
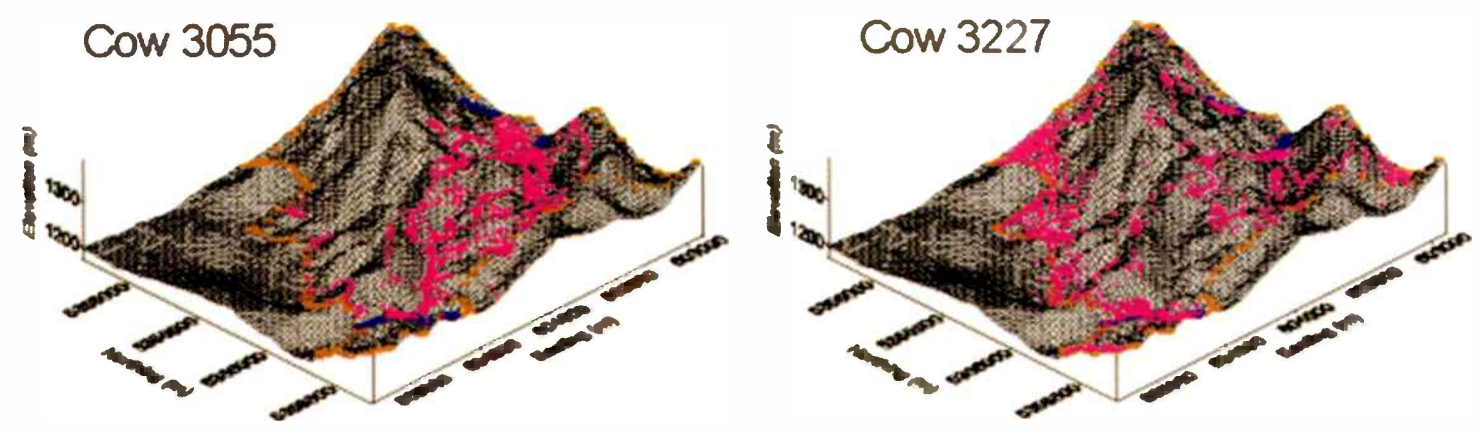

Fig. 2. Locations of 2 hill climber cows ( 0090 and 3102) and 2 bottom dweller cows ( 3055 and 3227$)$ during the 3-week observation period in late summer (Table 1). Locations were recorded every 10 minutes during the day (0500 to 2100 ) and every 20 minutes at night (2101 to 0459). Hill climbers were observed using steeper slopes and traveling farther vertically from water than bottom dwellers in this pasture during the previous year. 
Table 2. Least squares means $(+\mathrm{SE}$ ) of terrain use attributes from hill climber and bottom dweller cows based on locations recorded by GPS tracking collars at 0700 hours ${ }^{1}$.

\begin{tabular}{lccc}
\hline \hline Behavior & Hill climber & Bottom Dweller & P-Value \\
\hline Slope (degrees) & $17.4 \pm 1.2$ & $13.7 \pm 0.9$ & 0.04 \\
Horizontal distance to water $(\mathrm{m})$ & $606 \pm 73$ & $729 \pm 59$ & 0.22 \\
Vertical distance to water $(\mathrm{m})$ & $104 \pm 7$ & $62 \pm 6$ & $<0.01$ \\
Elevation $(\mathrm{m})$ & $1323 \pm 10$ & $1277 \pm 8$ & $<0.01$ \\
\hline
\end{tabular}

Least square means are based on 4 hill climber and 5 bottom dweller cows $(n=9)$. pasture. One hill climber cow (1179) was in all 8 visual zones (Fig. 1) during the early morning (0700 hour). Cow 2036 was observed in 3 visual zones at 0700 hour but was tracked for only 8 days. The other cows were in as few as 4 or as many as 7 of the visual zones at 0700 hour. Cows were never in the same visual zone at 0700 hour for more than 4 consecutive days. The majority of the time cows were in same visual zone for no more than 2 consecutive mornings. Cows visited at least 2 of the 3 water sources. Only 2 cows ( 3055 and 3024, bottom dwellers), did not visit all 3 water sources. One cow (3024) went to the same watering location for 9 consecutive days. The other cows did not go to the same watering location for more than 7 consecutive days.

At 0700 hour, hill climbers were on steeper slopes $(P=0.04)$ than bottom dwellers (Table 2). In addition, hill climbers were further vertically from water $(P=0.002)$ and at higher elevations $(P=0.006)$ than bottom dwellers. However, both groups of cows were at similar $(P=0.22)$ horizontal distances from water at 0700 hour.

When all of the tracking data were evaluated, hill climbers $(14.1 \%)$ spent more time $(\mathrm{P}=0.02)$ on steeper slopes ( 20 to 30 degrees) than did the bottom dwellers (6.5\%). These slopes made up $23.1 \%$ of the pasture. There was a tendency for hill climbers $(40.5 \%)$ to spend less time $(\mathrm{P}=$ $0.07)$ than bottom dwellers $(47.0 \%)$ on gentle slopes ( 0 to 10 degrees). Gentle slopes made up $22.3 \%$ of the pasture. Hill climbers and bottom dwellers used moderate slopes ( 10 to 20 degrees) similarly ( $P=$ 0.6 ). Cows spent $45.5 \%$ of their time on moderate slopes, which made up $53.1 \%$ of the pasture. Both hill climbers and bottom extremely steep slopes ( $>30$ degrees) and the difference in use between the 2 groups of cows was not important $(P=0.12)$. Extremely steep slopes made up only $1.5 \%$ of the pasture. The mean slope of the study pasture was 15.4 degrees.

Hill climbers $(13.8 \%)$ spent more time $(\mathrm{P}=0.01)$ at some of the higher elevations $(1310$ to $1340 \mathrm{~m})$ than bottom dwellers dwellers spent little time $(0.5 \%)$ on
(5.9\%). These elevations comprised $15.5 \%$ of the pasture. Hill climbers and bottom dwellers used other elevation zones similarly $(\mathrm{P}>0.05)$. The mean elevation in the study pasture was $1277 \mathrm{~m}$.

Hill climbers and bottom dwellers did not differ $(\mathrm{P}>0.1)$ with respect to horizontal distance to water. Cows spent about $58 \%$ of their time at distances greater than $200 \mathrm{~m}$ from water.

\section{Movement To and From Water}

Hill climber cows began traveling to water almost 1 hour later $(P=0.02)$ than bottom dweller cows (Table 3 ). Differences in ambient temperature when the cows began to travel to water were not important $(P=0.10)$. Both groups of cows left water between 1800 and 1830 hours $(P$ $=0.25$ ). Differences in the total time spent at water for hill climbers and bottom dwellers were not important $(P=0.24)$. Cows spent almost 8.5 hours near water. During this period, both hill climbers and bottom dwellers ( $P=0.55$, Table 3 ) spent the majority of their time resting (inactive) and remained near water. Both groups of cows $(P>0.1)$ spent 90 and $98 \%$ of their time within 100 and $200 \mathrm{~m}$ of the water source, respectively.

\section{Predicting Feeding Site Locations From Early Morning Observations}

The location of cows at 0700 hour was within $400 \mathrm{~m}$ for $87 \%$ of the GPS collar coordinates collected from 1 hour after leaving water to 1 hour before traveling to water (LW+1 to TW-1). Over half of the locations recorded within this period were within $200 \mathrm{~m}$ of the 0700 hour location (Fig. 3). The percentage of observations within $100,200,300$ and $400 \mathrm{~m}$ of the 0700 hour location was similar for hill climber and bottom dweller cows $(\mathrm{P}>0.2)$.

\section{Tortuousity of Grazing Pathways}

Grazing pathways of hill climber and bottom dweller cows did not differ $(P=$ 0.23 ) with respect to fractal dimension. Fractal dimensions of grazing pathways were less than 1.5 for all cows evaluated.

\section{Association Between Cows}

Two bottom dweller cows were in the same visual zone during the early morning ( 0700 hour) as often as $50 \%$ of the time and as infrequently as $8 \%$ of the time. Two cows would be expected to be in the same visual zone at the same time about $17 \%$ of the time based on chance alone. Overall, bottom dwellers were in the same visual zone about $25 \%$ of the time (Fig. 4), which tended to be higher than chance levels $(P<0.10)$. Bottom dwellers were at the same watering location about $46 \%$ of the time. Two cows would be expected to be at the same watering location at the same time about $33 \%$ of the time by chance alone. Bottom dwellers tended to be in the same location at levels greater than what would be expected by chance $(P<0.10)$.

Two hill climbing cows were in the same visual zone during the morning ( 0700 hour) as often as $57 \%$ of the time and as infrequently as $25 \%$ of the time. Overall, hill climbers were in the same visual zones about $34 \%$ of the time (Fig. 4), which was greater than what would be expected by chance $(\mathrm{P}<0.05)$. Hill climbers were at the same watering loca-
Table 3. Least squares means $( \pm \mathrm{SE}$ ) of the time cows began to travel to water (TW), time cows left water (LW), temperature when cows began to travel to water (TW-T), temperature when cows left water (LW-T), time at water and the percent of observations when cows were inactive for hill climber and bottom dweller treatments ${ }^{1}$.

\begin{tabular}{lccc}
\hline \hline Behavior & Hill climber & Bottom Dweller & P-Value \\
\hline $\begin{array}{l}\text { Time that cattle began to travel to water } \\
\text { (hour/minutes) }\end{array}$ & $1027 \pm 21$ & $0928 \pm 20$ & 0.02 \\
$\begin{array}{l}\text { Time that cattle left water } \\
\text { (hour/minutes) }\end{array}$ & $1836 \pm 22$ & $1809 \pm 21$ & 0.25 \\
$\begin{array}{l}\text { Temperature when cattle } \\
\text { travel to water }\left(\mathrm{C}^{\circ}\right)\end{array}$ & $23.4 \pm 1.2$ & $21.3 \pm 1.1$ & 0.10 \\
$\begin{array}{l}\text { Temperature when cattle left water }\left(\mathrm{C}^{\circ}\right) \\
\begin{array}{l}\text { Duration near water }(\mathrm{LW}-\mathrm{TW}, \text { hours) } \\
\text { Percent of observations when cows }\end{array}\end{array}$ & $26.2 \pm 0.8$ & $26.8 \pm 0.8$ & 0.44 \\
were inactive while at water $(\%)$ & $60.5 \pm 10.2$ & $5.7 \pm 0.4$ & 0.24 \\
\hline
\end{tabular}

${ }^{1}$ Least square means are based on 4 hill climber and 5 bottom dweller cows $(n=9)$. 


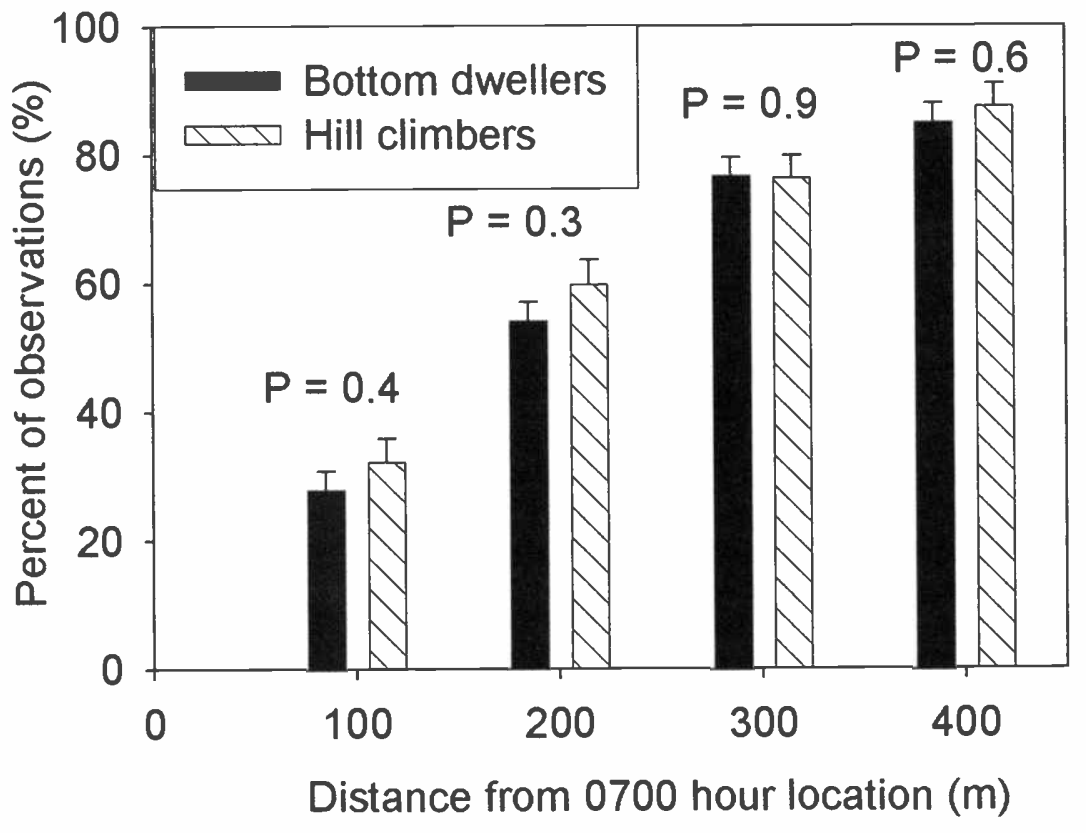

Fig. 3. Least square means ( $\pm \mathrm{SE}$ ) of the percentages of locations for hill climber and bottom dweller cows during the period beginning 1 hour after cows left water $(L W+1)$ until 1 hour before cows traveled to water (TW-1) that were within $100,200,300$, and $400 \mathrm{~m}$ of the 0700 hour cow location.

tions about $50 \%$ of the time, which was also greater than what would be expected by chance $(\mathrm{P}<0.05)$.

Some bottom dwellers and hill climbers were never in the same visual zones during the morning, while one pair (cows 2036 and 3226 ) was in the same visual zones as often as $43 \%$ of the time (Fig 4). Overall, hill climber and bottom dwellers were in the same visual zones about $15 \%$ of the time, which was not different from chance levels $(P>0.10)$. Hill climber and bottom dwellers were at the same watering location as often as expected by chance $(33 \%, \mathrm{P}>0.10)$.

\section{Discussion}

\section{Daily Activity Patterns}

Cows usually left water in the evening after 1800 hours, traveled to a selected area in the pasture, and remained close by until the following morning when they returned to water between 0930 and 1100 hours. The time that cows began to travel to water varied among individuals. However, cows left water at roughly the same time. Cattle usually have 2 major grazing bouts, 1 in the evening and 1 in the morning (Low et al. 1981, Ganskopp 2001). Data from this study suggest that the evening and morning grazing bouts and night resting periods occur in the same
Comparison of Hill Climber and

Bottom Dweller Cows

Within the same herd, cows can graze different portions of a pasture. Cows that were observed at higher elevations and steeper slopes in 1997 based on horseback observations (hill climbers) continued to use similar terrain types in 1998 when observed continuously with GPS collars. Similarly, cows that were observed on gentler slopes and lower elevations (bottom dwellers) used the same types of terrain during the following year. Both groups of cows left water at about the same time and traveled roughly the same horizontal distance from water, but the hill climbers spent more time on steeper slopes $\left(20-30^{\circ}\right)$, higher elevations $(1310-1340 \mathrm{~m})$ and were more willing to travel further vertically ( $42 \mathrm{~m}$ higher) from water than the bottom dwellers. The variation in terrain use by cows could be associated with differences in plant species composition or forage quality. Spatial preferences of cattle have been associated with species composition and forage quality factors such as standing nitrogen (Senft et al. 1985, Pinchak et al. 1991). However, species composition in the study pasture varies little with changes in slope or elevation. Limited forage sampling in the study pasture in 1998 suggested that crude protein concentration of grasses in the higher and steeper terrain (8.1\% CP) was not dramatically different $(P=0.20, \mathrm{df}=6)$ from that in more moderate terrain $(9.1 \% \mathrm{CP})$. Further research is needed to evaluate the effects of forage quality and quantity on the terrain use of individual cows.

The tortuousity of grazing paths of hill climbers and bottom dwellers was similar even though they sometimes grazed on different types of terrain. Both groups of cows traveled in a relatively straight path during the morning grazing bout. Data from this study does not support turning frequency and angle foraging mechanism described by Bailey et al. (1996) for explaining the time herbivores spend in nutrient-rich and nutrient-poor areas.

Bottom dwellers began traveling to water about 1 hour before the hill climber cows. This could be an approach to help identify differences in individual grazing patterns. Cows that travel to water earlier in the morning may be less likely to use steeper slopes and higher elevations than cows that travel to water later in the morning. Several authors (e.g., Roath and Krueger 1982, Howery et al. 1996, 1998) have suggested using individual animal selection as a management approach to 


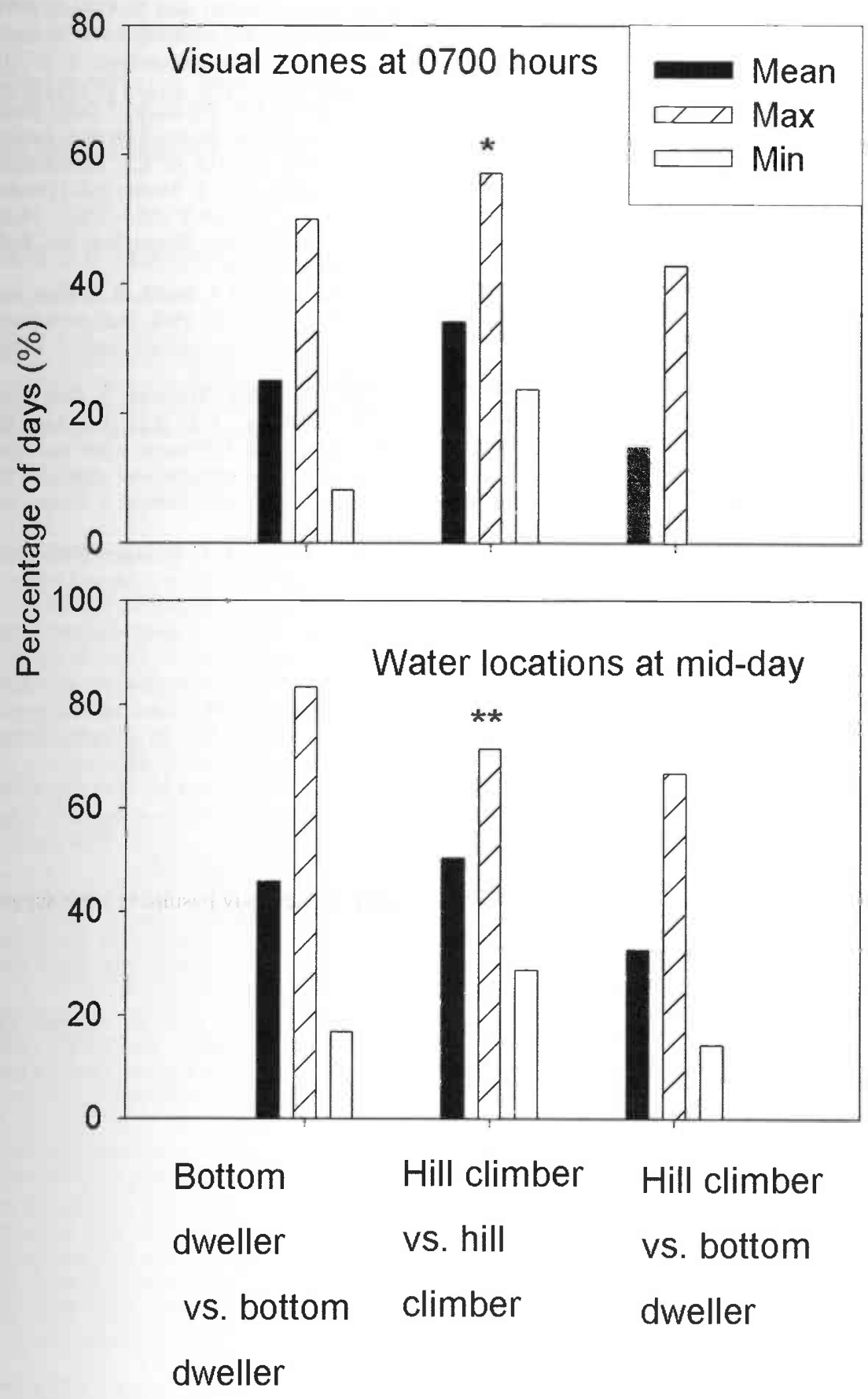

Fig. 4. Percentage of days that 2 focal cows were in the same visual zone at 0700 hours or same watering location during midday. Visual zones $(n=8)$ were areas that were not within line of sight because of topographical features or were greater than $500 \mathrm{~m}$ from other zones (Fig. 1). Watering locations $(n=3)$ were also separated by ridges or other relief. Maximum and minimum values represent pairs of cows that the highest or lowest percentage of days in the same visual zone or watering area, respectively. Means represent the average of the corresponding pairs of cows. The symbols * and $* *$ correspond to $\mathbf{P}<0.05$ and $P<0.01$, respectively.

increase the uniformity of grazing. This requires the identification of individual animal grazing patterns. Scan sampling of cow locations during the early morning requires a large labor commitment that

\section{Predicting Grazing Site Selection from Early Morning Locations}

Previous research (Bailey et al. 1990, $2001 \mathrm{a}, 2001 \mathrm{~b})$ used the locations of cows during the early morning as an indicator of where cows spend most of their time grazing. This was based on observer tracking of cows for 24-hour periods in central Australia (Low et al. 1981). In this study, cows were tracked continuously for periods up to 3 weeks. This tracking data shows that the locations of cows during the early morning were good predictors of where cows grazed during the previous evening and that morning. The majority of the observations during the evening, night and morning were within $200 \mathrm{~m}$ of the 0700 hour location.

The analyses of terrain use based on 0700 hour locations were similar to analyses using all locations. Hill climbers used steeper slopes and higher elevations than bottom dwellers, and there were no differences between cattle groups for horizontal distance to water using both data sets (0700 hour locations and all locations). The similarity in results from these 2 analyses supports the use of early morning locations as an indicator of where cows graze during the evening and morning bouts.

Scan sampling cow locations in the morning allows observers to identify individual differences in feeding site selection. Observations collected in the evening would also be effective except that observers have the potential to alter where cattle graze if viewing begins too early, and animals are still moving away from water. In addition, scan sampling becomes more difficult with approaching darkness. During the early morning, observers can travel to the pasture in the dark and begin observations when visibility is sufficient. Cows often begin grazing at daybreak (Low et al. 1981), and as opposed to evening animals usually do not travel extensively before they begin grazing.

\section{Association Between Cows}

Hill climber and bottom cows tracked in this study did not consistently graze together. Most of the time, focal cows could not see each other during the early morning grazing period. They were in different areas of the pasture. The only 2 cows (2036 and 3102) that were in the same visual zone for more than half of the time were both hill climbers and included the cow (2036) that was only tracked for 8 days. Even though cows within a group (hill climber vs hill climber or bottom dweller vs bottom dweller) were together 
more than expected by chance, focal cows did not appear to be within the same groups or subherds. Instead, these cows usually chose different areas of the pasture to graze, and over half of the time they went to different water sources.

Hill climber and bottom dweller cows were in the same visual zone or watering location at a frequency that would be expected by chance. Mosley (1999) suggested that differences in grazing patterns among cows were the result of social dominance, and subdominant cows avoided areas selected by dominant cows. In this study, Mosley's hypothesis would correspond to hill climbers avoiding bottom dwellers or vice versa. The observations from 9 cows tracked in this study do not support a social dominance explanation of cattle grazing patterns. Hill climbers and bottom dwellers were often in different parts of the pasture during resting (at water) and grazing periods even though animals within both groups regularly changed where they grazed and watered. Without being in visual sight of each other, it is unlikely that dominant animals could influence the behavior of subdominant animals. More research is needed to understand the effects of social interactions on cattle grazing patterns.

\section{Conclusions}

During late summer after leaving water in late afternoon, cows usually traveled to an area where they grazed during the evening, stayed at night and then grazed in the early morning. The location of cows during the early morning was a good indicator of where they grazed during the previous evening and during the rest of the morning grazing bout. Once cows traveled to water in the later part of the morning during late summer, they usually remained within $100 \mathrm{~m}$ of the water source until they left again in late afternoon. Individual cows within the same herd grazed different parts of the same pasture. Cows that used steeper slopes and higher elevations during the previous grazing season (hill climbers) continued to use rougher terrain than cows that used gentler slopes and lower elevations (bottom dwellers) the year before. The time that cows begin traveling to water may be a behavior that can help identify differences in individual grazing patterns. Bottom dweller cows began traveling to water about 1 hour before hill climber cows. Cows tracked in this study did not appear to have a strong social association with each other. Most of the time, they selected different areas of pasture to graze and water.

\section{Literature Cited}

Bailey, D.W. 1999. Influence of species, breed and type of animal on habitat selection, $\mathrm{p}$. 101-108. In: K.L. Launchbaugh, K.D. Sanders, and J.C. Mosley (eds.) Grazing behavior of livestock and wildlife. Idaho Forest, Wildlife and Range Exp. Sta. Bull. \#70. Moscow, Ida.

Bailey, D.W., J.W. Walker, and L.R. Rittenhouse. 1990. Sequential analysis of cattle location: day-to-day movement patterns. Appl. Anim. Behav. Sci. 25:137-148.

Bailey, D.W., D.D. Kress, D.C. Anderson, D.L. Boss, and K.C. Davis. 2001 b. Evaluation of $\mathrm{Fl}$ crosses from Angus, Charolais, Salers, Piedmontese, Tarentaise and Hereford sires V: Grazing distribution patterns. Proc., West. Sec. Amer. Soc. Anim. Sci. 52:110-113.

Bailey, D.W., D.D. Kress, D.C. Anderson, D.L. Boss, and E.T. Miller. 2001a. Relationship between terrain use and performance of beef cows grazing foothill rangeland. J. Anim. Sci. 79:1883-1891.

Bailey, D.W., J.E. Gross, E.A. Laca, L.R. Rittenhouse, M.B. Coughenour, D.M. Swift, and P.L. Sims. 1996. Mechanisms that result in large herbivore grazing distribution patterns. J. Range Manage. 49:386-400.

Etzenhouser, M.J., M.K. Owens, D.E. Spalinger, and S.B Murden. 1998. Foraging behavior of browsing ruminants in a heterogeneous landscape. Landscape Ecol. 13:55-64.

Ganskopp, D. 2001. Manipulating cattle distribution with salt and water in large arid-land pastures: a GPS/GIS assessment. Appl. Anim. Behav. Sci. 73:251-262.

Howery, L.D., F.D. Provenza, and R.E. Banner. 1998. Social and environmental factors influence cattle distribution. Appl. Anim. Behav. Sci. 55:231-244.

Howery L.D., F.D. Provenza, R.E. Banner, and C.B. Scott. 1996. Differences in home range and habitat use among individuals in a cattle herd. Appl. Anim. Behav. Sci. 49:305-320.

Lehner, P.N. 1979. Handbook of ethological methods. Garland STPM Press, New York, N.Y.

Low, W.A., R.L. Tweedie, C.B.H. Edwards, R.M. Hodder, K.W.J. Malafant, and R.B. Cunnigham. 1981. The influence of environment on daily maintenance behavior of free-ranging Shorthorn cows in central Australia. 1. General introduction and descriptive analysis of day-long activities. Appl. Anim. Ethology 7:11-26.

Mead, R., R.N. Curnow, and A.M. Hasted. 1993. Statistical methods in agriculture and experimental biology, $2^{\text {nd }}$ Ed. Chapman and Hall, London, U.K.

Milne, B.T. 1990. Lessons from applying fractal models to landscape patterns. In: M.G. Turner and R.H. Gardner (eds.) Quantitative methods in landscape ecology. Ecological Studies Vol. 82, Springer-Verlag, New York, N.Y.
Moen, R., J. Pastor, and Y. Cohen. 1997. Accuracy of GPS telemetry collar locations with differential correction. J. Wildl. Manage. 61:530-539.

Mosley, J.C. 1999. Influence of social dominance on habitat selection by free-ranging ungulates, p. 109-118. In: K.L. Launchbaugh, K.D. Sanders, and J.C. Mosley (eds.) Grazing behavior of livestock and wildlife. Idaho Forest, Wildlife and Range Exp. Sta. Bull. \#70. Moscow, Ida.

Pinchack, W.E., M.A. Smith, R.H. Hart, and J.W. Waggoner, Jr. 1991. Beef cattle distribution patterns on foothill range. J. Range Manage. 44:267-275.

Porath, M.L., P.A. Momont, T. DelCurto, N.R. Rimbey, J.A. Tanaka, and M. McInnis. 2002. Offstream water and trace mineral salt as management strategies for improved cattle distribution. J. Anim. Sci. 80:346-356.

Roath, L. R. and W. C. Krueger. 1982. Cattle grazing and behavior on a forested range. $\mathrm{J}$. Range Manage. 35: 332-338.

SAS. 1985. SAS user's guide: Statistics. SAS Inst., Inc. Cary, N.C.

Senft, R.L., L.R. Rittenhouse, and R.G. Woodmansee. 1985. Factors influencing patterns of cattle behavior on shortgrass steppe. J. Range Manage. 38:295-299.

Steel, R.G.D. and J.H. Torrie. 1980 . Principles and procedures of statistics: A biometrical approach, $2^{\text {nd }} \mathrm{Ed}$. McGraw-Hill Book Co., New York, N.Y.

Theobald, D.M. 1999. Movement calculator version 1. Avenue program written for ArcView to calculate fractal dimension. Natural Resource Ecology Lab, Colo. State Univ., Fort Collins, Colo.

Turner, L.W., M.C. Udal, B.T. Larson, and S.A. Shearer. 2000. Monitoring cattle behavior and pasture use with GPS and GIS. Can. J. Anim. Sci. 80:405-413. 